\title{
THE EFFECT OF FINANCIAL RATIO ON FINANCIAL DISTRESS IN PREDICTING BANKRUPTCY
}

\author{
Arif Darmawan $^{1)}$, Joko Supriyanto ${ }^{2)}$ \\ Managerial Accounting Department, Politeknik Negeri Batam \\ Jl. Ahmad Yani, Batam Centre, Batam 29461, Indonesia \\ 1)E-mail: arif.darmawan4@gmail.com \\ ${ }^{2)}$ E-mail: jozutshimi@gmail.com
}

\begin{abstract}
This study was conducted to investigate Financial Distress in mining companies listed on the Indonesian Stock Exchange (BEI) during the 2011-2014 period using the Altman Z-Score Modification. Total sample that gathered from mining companies is 119 companies, analytical techniques used in this study is the Altman Z-score that consists of four ratios, which are the Net Working Capital to Total Assets (X1), Retained Earnings to Total Assets (X2), Earnings Before Interest and Tax to Total asset (X3), Market Value of Equity to Book Value of Debt (X4.). This test used SPSS 22 to test the hypothesis, the hypothesis testing results are: Net Working Capital to Total Assets has a positive effect on Financial Distress, Retained Earnings to Total Assets has a positive effect on Financial Distress, Earnings Before Interest and Tax to Total Assets has a positive effect on Financial Distress, Book Value of Equity to Total Liabilities has a positive effect on Financial Distress. This study only used mining companies sector, the further research is recommended to use the other sector companies that have larger numbers of samples.
\end{abstract}

Keywords: Financial Distress, Altman Z-Score Modification, Bankcruptcy, Prediction 


\section{Introduction}

Natural resource is one of the sectors that have an important role in development in Indonesia, which is the lifeblood of the economy capable of sustaining welfare in Indonesia. Indonesia has abundant mineral resources such as petroleum, natural gas, coal, and other minerals. Indonesia is one of the largest coal producer and exporter in the world since 2005. In 2014 Indonesia became the country's third-largest coal producer in the world as much as 281.7 Mt (Statistical Review of World Energy, 2015).

The mining sector remains even become one of the main sectors that drive the economy of Indonesia. Every year, the mining sector is not on the graph is fixed, its shares declining growth and economic contribution of the mining sector to Indonesia declined. It is also caused by the global economic slowdown. With the decline in energy prices impact on decreasing the investment climate, during the period 2015-2016 the global economy slows down (Sindo Newspaper 2015)

Commodity prices have been declining since the third quarter of 2014 until September 2015, oil prices have declined by $60 \%$, gas prices decreased $52 \%$, and at the same time coal prices also decreased by $45 \%$. Prices of non-energy mines also decreased, it becomes very troubling to affect the prospects of mining and energy sector investments.

A decrease is whether the company is able to move in the mining sector in maintaining the financial viability of the company, whether it affects the continuity of the company or even going to make the company bankrupt. Bankruptcy can be analyzed using financial ratios of the company's financial statements issued by the companies Winarto (2006). Ratio analysis is an analysis that is often used in assessing the company's financial performance, but the ratio analysis showing only one aspect without being able to associate with other aspects. Each ratio has a usability and provide an indication of the different information regarding the company's financial health, the ratio sometimes conflicting with each other. To complete the lack of analysis of the ratio of researchers used an analysis tool that can connect multiple ratios at once, namely Zscore analysis

The previous study Altman (1968) has identified five financial ratios that can be used to detect the bankruptcy of the company before the company experienced bankruptcy. Five ratios consist of cash flow to total debt, net income to total assets, total debt to total assets, working capital to total assets, and current ratio. Altman also found certain ratios such as liquidity and leverage give fair in detecting the bankruptcy of the enterprise. While that measure financial distress research conducted by Luciana (2003) measure of financial distress in a way that the company is said to be experiencing financial distress if the company had operating income and negative equity book value. Research Financial distress using the Altman Z-score modification, using four ratios, namely; Net Working Capital to Total Assets, Retained Earnings to Total Assets, Earnings Before Interest and Tax to Total Assets and Book Value of Equity to Total Liability. All four of these ratios is able to predict Financial distress in the company.

Research in Indonesia itself regarding potential analysis ever undertaken by Kamal (2010) by examining the banking company went public listed on the Indonesia Stock Exchange by using financial data 2008-2010 period using a variable liquidity, profitability and activity. Mokhamad \& Mawardi (2012) conducted research on financial distress using a sample of 88 manufacturing companies went public listed on the Indonesia Stock Exchange.

The studies above become empirical evidence that financial ratios can be used as a tool to detect the condition of financial distress and bankruptcies of companies with very accurate. Thus the researchers conducted this study to determine the soundness of mining companies in Indonesia. Financial distress occurs before the bankruptcy. Model of financial distress need to be developed, because by knowing the condition of Financial Distress from a company earlier, can let them do the actions to anticipate the conditions that lead to bankruptcy. Bankruptcy is a very serious problem and costly, it would be good if the early warning that can detect potential bankruptcy of a 
company, it would be helpful for the management and for investors. Management can make improvements to improve the performance of the company and for the creditors and shareholders can make preparations to cope with the possibility that bad.

To overcome the drawbacks of the original formula Altman Z-score there are some solutions. To calculate a private company cannot calculate the Market Value of Equity therefore performs the repair formula called Altman Z-score Modification. Altman Modification replaces X4 from the Market Value of Equity / Total Liabilities to Book Value of Equity / Liabilities. As for the non-manufacturing companies eliminate X5 ie Assets Turnover for non-manufacturing companies generally offer Service not sell goods.

Based on the background problems above, researchers interested in studying more about predictive analytics bankruptcy on mining companies in Indonesia Stock Exchange. Researcher took the title EFFECT OF

FINANCIAL RATIOS FINANCIAL DISTRESS IN PREDICTING BANKRUPTCY.

\section{Theoretical Foundations}

\section{Bankruptcy}

Bankruptcy is a failure or loss of financial capability in the company in some sense defined by Martin and Fahkrurozie (2007):

a. Economic Distressed

Economic Distress is a condition in which the company lost revenue to cover its own cost, in terms of the company's revenue is less than the capital as well as a greater obligation than the incoming cash flow. This happens if the cash flow is not as expected. b. Financial Distress

Understanding financial distress company has funding difficulties, both in terms of working capital or in terms of cash. As asset liability management has a role to regulate and keep the company is not exposed to financial distress. The company will undergo a phase of bankruptcy fairly quickly if a company experiencing economic difficulties, from which was already sick sicker and then went bankrupt.

According to Toto (2011) bankruptcy is a condition where the company no longer able to repay their obligations. This condition does not appear so at the company, there are early indications that can be seen when the financial statements can be analyzed carefully. Financial ratios can be used as an indication of a company's bankruptcy.

\section{Altman Z-Score Model}

According to Willy (2011), a model Altman Z-score is a multivariate analysis model that can predict the bankruptcy of companies with a level of accuracy and precision are relatively trustworthy. This model has an accuracy of $95 \%$ when using the data one year before the bankruptcy. This model uses discriminant analysis to obtain the predicted level bankruptcy of the company and its financial performance using four variable ratio follows: Net Working Capital to Total Assets, Retained Earnings to Total Assets, Earnings Before Interest and Tax to Total Assets, Book Value of Equity to Total Assets,

To determine a company's financial condition Altman (1968) developed a model that has been modified to be applied to all types of enterprises. Altman model formulation that has been modified as follows:

$Z^{\prime \prime}=6.56 \mathrm{X} 1+3.26 \mathrm{X} 2+6.72 \times 3+1.05 \times 4$

Information:

$\mathrm{X} 1=($ Current Assets - Current Liabilities $) /$ Total Assets

X2 = Retained Earnings / Total Assets

X3 = Earnings Before Interest and Taxes / Total Assets

X4 = Book Value of Equity / Total Liabilities

In this modification Altman model has a score value to determine the condition of the company into three zones. Score 2.6 and larger show that companies in the safe zone, and below 1.1 indicates in the danger zone. Value 1.1 - 2.6 represents a gray zone where there is no clear prediction.

\section{Financial Statement}

These financial statements are statements that are expected to provide company information combined with other information such as the information industry 
and the economy, the report is expected to provide an overview of the prospects and risks in the company (Hanafi and Halim, 2002). These financial statements are part of the financial reporting process. The financial statements include: Balance Sheet, Statement of Comprehensive Income, changes in equity, statement of changes in financial position can be presented in the form of a cash flow statement or funds flow statement, notes and other statements and explanatory material that are an integral part of the financial statements or sustainable.

\section{Agency Theory}

Within companies often involve the owner (Principal) and manager (Agent), owners of facilities and operational funds while the manager had our obligations to manage the company and generate profits to enhance the prosperity of the owner. The aim of the company is to the prosperity of the shareholders, or the so-called maximizing stock prices. In fact, contrary to the goal, because the manager is appointed and is formed by the owners so they act in the best interests of the owners.

For example manager reported the condition of the company as if the target is reached. Shareholders view manager is working properly and make a profit. But if this is constantly done by the manager, the company will experience problems one experienced Financial Distress. This could happen if the lack of effective oversight by the shareholders, the agency theory is used for decision making and evaluating and dividing the result in accordance with the employment contract has been agreed.

\section{Financial Distress}

Financial distress is a situation when a company fails to meet its obligations to the debtor because the company has insufficient funds with total assets less total liabilities, and does not achieve the economic objectives of companies that profit (Almilia \& Herdiningtyas 2005). Indicators of financial distress are:

The decline in sales volume due to the influence of declining consumer demand. The increase in production costs that add fund its operations, the level of the increasingly fierce competition with competitors, failure to carry out the expansion, inefficiency in collecting debts, lack of support banking facility (credit) and the high degree of dependence on receivables. The indicator that must be observed by external parties are:

Decreased dividends that are distributed to the shareholders, the decrease in profit continuously even until the emergence of losses, closed or sold one or more business units, dismissal of employees, the resignation of top executives and the stock price continued to fall in the capital market.

\section{Literature Review}

From previous research that Sulub (2014) have investigated the predictive power of the model Altman $\mathrm{Z}$-score to the multinational companies and taken a sample of 10 companies were selected randomly and evenly to the two groups failed and non-failed company. For the prediction accuracy of the company's financial distress was found failed in the predictive power of $70 \%$ while the company's nonfailed on a predictive power of $50 \%$.

Johansson \& Kumbaro (2011) conducted a study that aims to determine the performance of a purely numerical bankruptcy during the economic downturn from 2007 to 2010 in the manufacturing and nonmanufacturing. This method has the accuracy of $70 \%$ - $85 \%$ in identifying the company.

Odipo \& Sitati (2008) investigated whether Altman model can predict business failure in Kenya with a sample of 20 companies, 10 listed companies and 10 companies were delisted at the Nairobi Stock Exchange during the period 1989 - 2008. 10 companies failed analyzed show the predicted success of $80 \%$. 10 companies predicted non-failed shows this model successfully demonstrated the validity of $90 \%$. Show Altman model is useful for investors in the Kenyan market.

Alifiah (2014) predicted the financial distress in the company's services and trade sectors in Malaysia using independent variables that can predict the financial 
distress of companies using debt ratio, total asset turnover ratio, the ratio of working capital, net income divided by total assets and the base lending rate. The independent variables can be used to predict financial distress. Celli (2015) examine the model Altman Zscore for predicting a company listed on the Italian Stock Exchange (ISE) using a data sample of 102 companies from 1995 through 2013, 51 companies delisted and 51 non-delisting the company. The results of this study Altman Z-score models can be applied to the context in Italy by taking into account some important points there.

Bal (2015) conducted a study using the Altman Zscore model of the FMCG companies to cover the period 2011 to 2015 . The results showed all companies have a very good financial position three years ago except Godrej in 2014. Mahama (2015) using the Altman Z-score to determine the financial difficulties at the 10 companies listed on the Ghana Stock Exchange (GSE). The data used in this study were taken from the website ARG covers the period 2007 to 2013 . The study found 6 companies are not in danger of financial difficulties, the 2 companies in trouble and two more in a state of bankruptcy.

The study of domestic by Mokhamad \& Mawardi (2012) was using 88 manufacturing company that went public on the period of 2008 - 2010. In this study 10 companies experiencing distress and 78 suffered non-distress, Altman model is able to predict the financial distress that affect the company's bankruptcy. Kamal (2012) conducted a study using all four ratios Altman Z-score modification of the Net Working Capital to Total Assets, Retained Earnings to Total Assets, Earnings Before Interest and Tax to Total Assets and Book Value of Equity to Total Liability positive effect on Financial Distress.

\section{Hypotheses}

Working Capital Working capital which is obtained from the calculation of current assets minus current liabilities, both of these elements can be encountered on the balance sheet. In a previous study Kamal (2010) using this ratio, this ratio shows the company's ability to generate net working capital of all its total assets. In research Kamal (2010) this ratio has positive influence on financial distress, according to Kamal (2010) if the ratio is a positive influence on the company's financial distress declared no financial distress. This is because the working capital consists of Current Current assets and liabilities if the value of working capital the greater the mean value of current assets is greater than the value of current liabilitie so indicative of a company free from financial distress also increases. Then the hypothesis to be tested as follows:

\section{H1 = Net Working Capital to Total Assets positive effect on Financial Distress.}

This ratio indicates the company's ability to generate retained earnings of the total assets of the company. Kamal (2010) also use this ratio to determine the financial companies experiencing financial distress or not, from his research have positive effect on the ratio of financial distress, Kamal (2010) found a positive effect when this ratio then the company otherwise would not be bankrupt. This means that the larger the company's retained earnings then freed indication of financial distress. Then the hypothesis to be tested as follows:

\section{H2 = Retained Earnings to Total Asset positive effect on Financial Distress}

Furthermore, this ratio shows the company's ability to generate profits from the company's assets before tax and interest payments. Kamal (2010) uses this ratio in research and positive effect on financial distress. Kamal (2010) argues, if this ratio is a positive influence on the company's financial distress will not experience financial distress. This means if the total income generated by the assets have not been used to pay taxes and interest then an indication of a company free from financial distress increases. Then the hypothesis to be tested as follows:

\section{H3 = Earnings Before Interest and Tax to Total} Asset positive effect on Financial Distress

The last ratio shows the extent to which the company financed by debt or not. In research Kamal (2010) earlier this ratio positive effect on financial distress, kamal thought if this ratio is a positive influence on the company's financial distress will experience financial distress and even bankruptcy. This is because the 
greater the value Book Value of Equity, the company is increasingly using debt as an indication of the company's capital and the greater bankruptcy.

Previous researchers Kamal (2010) have proven to four of these ratios positive effect on Financial distress, according to Mustafa Kamal (2010) when the value of the ratio of Net Working Capital to Total Assets, Retained Earnings to Total Assets and Earnings Before Interest and Tax to Total Assets is positive, then the company will not experience financial distress. As for the ratio of Book Value of Equity to Total Liability is positive, the company will not experience financial distress. Then the hypothesis to be tested as follows:

H4 = Book Value of Equity to Total Liabilities positive effect on Financial Distress.

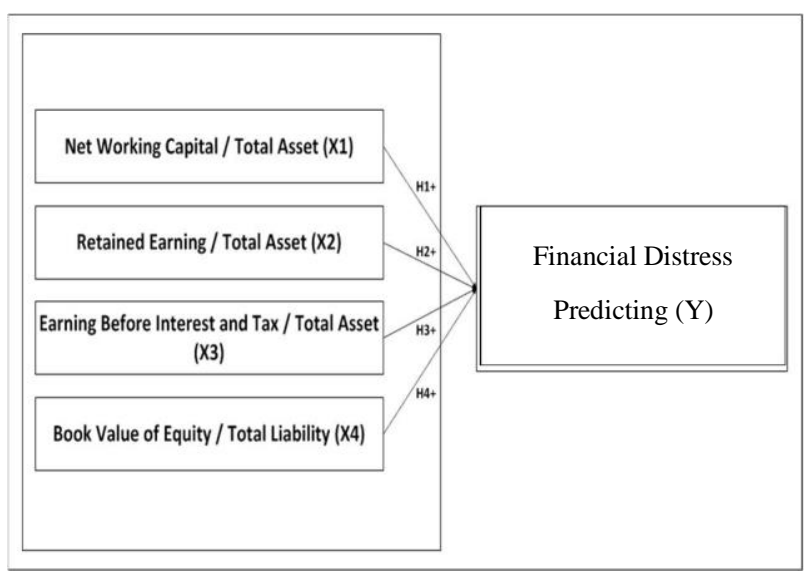

Figure 1 Research Model

To get a variable $\mathrm{X} 1$ used financial ratios Net Working Capital divided by Total Assets, which affects Variable $\mathrm{Y}$ ie Financial Distress who became the first hypothesis. To get X2 used financial ratios Retained Earnings divided by Total Assets, which affects Variable $\mathrm{Y}$ ie Financial Distress being hypotheses to two, and to find the variable X3 used financial ratios Earnings Before Interest and Tax divided by Total Assets, which affects the variable $\mathrm{Y}$ is Financial Distress who became the third hypothesis. To get a variable $\mathrm{X} 4$ used financial ratios Book Value of Equity divided by Total Liability affecting the variable $\mathrm{Y}$ is Financial Distress who became the fourth hypothesis. This study models can be seen in Figure 1.

\section{Research Method}

\section{Type and Data Source}

The method used in this research is quantitative approach. Research method with quantitative approach is the study of objects with the aim of explaining the facts systematically factually and accurately on the phenomenon to be investigated. The reason research using quantitative approach in this study because the source data used are secondary data from the financial statements of companies listed on the Indonesia Stock Exchange (database).

\section{Sampling Techniques}

Samples were taken and used in this study is a mining company listed on the Indonesia Stock Exchange period 2011 to 2014 annual report that the company is complete and has been audited.

The sampling technique in this study was using purposive sampling method. Purposive sampling method is a method that is using certain criteria in determining the sample to be used in research. The criteria which have been determined by researchers for sampling as follows:

a. The mining company listed on the Indonesia Stock Exchange.

b. Using the company's Annual Report data is complete as of December 31 of the year 2011 until 2014.

\section{Data Collecting and Processing Techniques}

Data collection techniques used in this study is the documentation method, which uses data sources that are already available, by downloading the financial statements are available on the website www.idx.co.id (database)

In this study, the data used is a model cross section. According to Gujarati (2003) Cross section is a data that consists of one or more variables collected at the same time. Data processing techniques in this study using IBM SPSS version 22 program. 


\section{Variables}

\section{Dependent Variables}

The dependent variable is the variable that is affected by the independent variable, dependent variable in this study is the Financial Distress, Financial Distress is a condition when the company is experiencing financial difficulties, the dependent variable is influenced by four independent variables.

To measure the dependent variable using the Altman Z-score formula as follows:

$$
Z \text { "= 6.56X1 + 3.26X2 + 6.72X3 + 1.05X4 }
$$

Of the four independent variables do calculations using formulas that have been determined are then summed to obtain the $\mathrm{Z}$ value or the value of the dependent variable are searched.

\section{Independent variables}

The independent variables are variables that affect the dependent variable, independent variables in this study are four variables:

\section{Net Working Capital to Total Assets}

Net Working Capital is current assets less current liabilities. Used to measure the liquidity of the total assets and working capital position. This variable can affect the dependent variable Financial Distress because if Net Working Capital has a positive value higher than the Financial Distress, the company is said to be capable of or in good condition, so it is not included in the condition or experience Financial Distress. X1 is measured by the Net Working Capital to Total Assets.

$$
\mathbf{X} 1=
$$

\section{Retained Earnings to Total Assets}

Retained Earnings to Total Asset useful to measure whether the cumulative profits were able to offset the amount of assets. This ratio shows the company's ability to generate retained earnings are derived from the total assets of the company. Retained earnings is an undistributed profits to shareholders. This ratio will have a positive value when an increase in retained earnings holding. X2 measured by Retained Earnings to Total Assets.
$\mathrm{X} 2=$

\section{Earnings Before Interest and Taxes to Total Assets} This variable is useful to measure the profitability of a company without seeing how big the debt of the company. If the value of the corporate debt each year increased the value of Financial Distress also decreased, because otherwise the company is able to generate earnings before taxes. X3 is measured by Earnings Before Interest and Tax to Total Assets.

$\mathbf{X} 3=$

$$
\text { ( ) }
$$

\section{Book Value of Equity to Total Liabilities}

Book Value of Equity to Total Liability is the ratio used to measure the extent of corporate assets financed by debt. If the company has a ratio of Book Value of Equity to Total Liability increasing from previous periods it can be said that the amount of debt the company has also increased. This ratio indicates that the company's total liabilities greater than total assets.

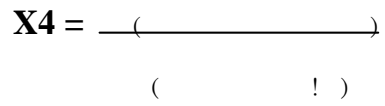

\section{Data Analysis Techniques}

To determine the relationship between the independent variables with the dependent variable, the analysis of data using multiple linear regression test, classic assumption test and test hypotheses.

\section{Result and Discussion}

\section{Samples}

In this study, sampling method Sampling Purpose includes a mining company listed on the Indonesia Stock Exchange (BEI) in the period 2011-2014. Listed financial statements are using the Rupiah currency. Total samples obtained were 42 companies with a method Cross Section, then the total number of samples during four years a total of 119 companies. For criteria and the number of samples of each period are presented in Table 1 as follows: 
Table 1 Samples Calculation

\begin{tabular}{|l|c|c|c|c|}
\hline \multicolumn{1}{|c|}{ Criteria } & $\mathbf{2 0 1 1}$ & $\mathbf{2 0 1 2}$ & $\mathbf{2 0 1 3}$ & $\mathbf{2 0 1 4}$ \\
\hline $\begin{array}{l}\text { Companies listed } \\
\text { on Indonesian } \\
\text { Stock Exchange }\end{array}$ & $\mathbf{4 2 8}$ & $\mathbf{4 4 6}$ & $\mathbf{4 8 7}$ & $\mathbf{5 1 0}$ \\
\hline $\begin{array}{l}\text { Delisted } \\
\text { Companies }\end{array}$ & $\mathbf{5}$ & $\mathbf{4}$ & $\mathbf{7}$ & $\mathbf{1}$ \\
\hline $\begin{array}{l}\text { Companies on } \\
\text { Mining Sector }\end{array}$ & $\mathbf{3 0}$ & $\mathbf{3 5}$ & $\mathbf{3 9}$ & $\mathbf{4 0}$ \\
\hline $\begin{array}{l}\text { Financial } \\
\text { Statements That } \\
\text { are Not Completed }\end{array}$ & $\mathbf{3 0}$ & $\mathbf{3 0}$ & $\mathbf{3 0}$ & $\mathbf{2 9}$ \\
\hline Total Samples & & & \\
\hline
\end{tabular}

\section{Descriptive Statistics}

Testing instrument in this study using descriptive statistics to describe the characteristics of each variable. Aims to recognize the pattern of a number of data, summarize the data and information in order to present the desired shape. The test results of descriptive statistics presented in Table 2 below is the data that is free of Outlier Data is data that deviate from the set of data that need to be eliminated.

Table 2 Statistics Descriptive

\begin{tabular}{|l|c|c|}
\hline \multicolumn{2}{|c|}{ Descriptive Statistics } \\
\hline & N & Mean \\
\hline WCTA & 119 & 0,15012 \\
\hline RETA & 119 & 0,11171 \\
\hline EBIT & 119 & 0,02803 \\
\hline BVOE & 119 & 0,04282 \\
\hline FD & 119 & 1,58221 \\
\hline Valid N (listwise) & 119 & \\
\hline
\end{tabular}

From table 2 it can be seen characteristics Financial companies experiencing distress as many as 119 companies from 2011-2014. The average value of the entire company WCTA amounted to 0.15012 .

Financial distress variables showed a positive value of 1.58221 is a portrait of the company into a positive samples experiencing financial difficulties and to improve the condition. RETA variables showed a value of 0.11171 which indicates a positive value associated with Financial distress Financial distress is likely to experience a little. This is because the company is able to demonstrate the ability to generate retained earnings, is positive, then the company is able to carry out major operations, increased corporate profits. While the value for the variable EBIT of 0.02803 is positive, then it is likely to bankrupt a small company, it is because in this ratio to see the company's ability to generate earnings before income taxes, on the positive results of the company otherwise afford. While the value of the variable BVOE of 0.04282 is positive, indicating that the company is financed by debt levels are still at a reasonable category, but the possibility of bankruptcy still exists.

\section{Discussion}

Table 3 Hypotheses Test Results

\begin{tabular}{|c|c|c|c|c|c|c|}
\hline \multirow[t]{2}{*}{ Rasio } & \multicolumn{2}{|c|}{$\begin{array}{l}\text { Unstandardized } \\
\text { Coefficients }\end{array}$} & \multirow{2}{*}{$\begin{array}{c}\text { Standardized } \\
\text { Coefficients }\end{array}$} & \multirow{2}{*}{$\begin{array}{l}\mathrm{RSq} \\
\text { uare }\end{array}$} & \multirow[t]{2}{*}{$\mathrm{t}$} & \multirow[t]{2}{*}{ Sig. } \\
\hline & B & $\begin{array}{l}\text { Std } \\
\text { Error }\end{array}$ & & & & \\
\hline \multicolumn{7}{|c|}{ H1 } \\
\hline $\begin{array}{l}\text { (Const } \\
\text { ant) }\end{array}$ & 8.856 & .000 & & & .290 & .772 \\
\hline $\begin{array}{c}\mathrm{WCT} \\
\mathrm{A} \\
\end{array}$ & 6.559 & .001 & .558 & .250 & $\begin{array}{r}6284 \\
.034 \\
\end{array}$ & .000 \\
\hline \multicolumn{7}{|c|}{ H2 } \\
\hline $\begin{array}{c}\text { (Const } \\
\text { ant) }\end{array}$ & 8.856 & .000 & & & .290 & .772 \\
\hline RETA & 3.260 & .001 & .419 & .250 & $\begin{array}{l}4560 \\
.728 \\
\end{array}$ & .000 \\
\hline \multicolumn{7}{|c|}{ H3 } \\
\hline $\begin{array}{c}\text { (Const } \\
\text { ant) }\end{array}$ & 8.856 & .000 & & & .290 & .772 \\
\hline EBIT & 6.719 & .002 & .275 & .250 & $\begin{array}{l}2713 \\
.503 \\
\end{array}$ & .000 \\
\hline \multicolumn{7}{|c|}{ H4 } \\
\hline $\begin{array}{l}\text { (Const } \\
\text { ant) }\end{array}$ & 8.856 & .000 & & & .290 & .772 \\
\hline BVOE & 1.049 & .001 & .102 & .250 & $\begin{array}{l}1248 \\
.173 \\
\end{array}$ & .000 \\
\hline
\end{tabular}

\section{Net Working Capital to Total Assets has Positive Effect on Financial Distress.}

Results of testing the hypothesis (H1) indicates that the Net Working Capital to Total Assets positive effect on Financial Distress. The results of this study are consistent with research conducted by Kamal (2010) this ratio has positive influence on financial distress, according to Kamal (2010) if the ratio is a positive influence on the company's financial distress declared no financial distress.

This hypothesis using a ratio that aims to measure the amount of current assets compared to current liabilities of the company to predict bankruptcy. If the working capital each year has increased the value free of Financial Distress higher. This is because the company is able to demonstrate the ability to generate working capital net current assets is greater than the current 
debts. The higher the ratio value WCTA then it is likely the company is free from the higher financial distress.

\section{Retained Earnings to Total Asset has Positive Effect on Financial Distress.}

Results of testing hypotheses two (H2) indicates that the variable RETA has a probability of 0.000 , this result qualifies Significance $<0.025$ so it can be concluded Retained Earnings to Total Asset positive effect on Financial Distress. The results of this study are consistent with research conducted by Kamal (2010). Kamal (2010) also use this ratio to determine the financial companies experiencing financial distress or not, from his research have positive effect on the ratio of financial distress, Kamal (2010) found a positive effect when this ratio then the company otherwise would not be bankrupt.

Retained Earnings is a value that indicates the company's ability to generate retained earnings of the total assets of the company. If the company is able to demonstrate the ability to generate retained earnings greater than the previous year, the company is declared not in financial distress or free from bankruptcy. The higher the ratio, the possibility that the company RETA free of increased financial distress.

\section{Earnings Before Interest and Tax to Total Asset has Positive Effect on Financial Distress.}

Results of testing three hypotheses (H3) showed that Earnings Before Interest and Tax to Total Asset positive effect on Financial Distress. The results of this study are consistent with research conducted by Kamal (2010) uses this ratio in research and positive effect on financial distress. Kamal (2010) argues, if this ratio is a positive influence on the company's financial distress will not experience financial distress.

EBIT is an operating income for the accounting period. EBIT is used to compare the rate of profit of the company with similar companies that may have high levels of debt or different tax liability, if the test results show that a high EBIT, the company does not belong to the group of companies experiencing financial distress. This is because the company is able to generate earnings before tax and interest payments. The higher the ratio of EBIT then freed from the possibility of financial distress also higher.

\section{Book Value of Equity to Total Liabilities has Positive Effect on Financial Distress.}

Results of testing the hypothesis of four (H4) showed that the Book Value of Equity to Total Liabilities positive effect on Financial Distress. The results of this study are consistent with research conducted by Kamal (2010) have proven to four of these ratios positive effect on Financial distress, according to Mustafa Kamal (2010) when the value of the ratio of Net Working Capital to Total Assets, Retained Earnings to Total Assets and Earnings before Interest and Tax to Total Asset high value then the company will not experience financial distress, and to the ratio of Book Value of Equity to Total Liability high value, the company will also be free from financial distress.

$\mathrm{BVOE}$ is a ratio used to measure the level of resource management company funds derived from debt. Value ratios are higher in this variable is the reason why companies are not included into the category of financial distress, because if a company uses debt funds that the lower the value of this ratio will be higher and indicate that the company is not experiencing financial difficulties in meeting its obligations, amounting to little. Due to unlock the value of the ratio BVOE done by way of capital divided by debt. The lower the ratio value BVOE the higher the possibility that the company is free from financial distress.

\section{Conclusion}

This study aims to investigate whether this ratio to four positive effect on Financial Distress. Both know the companies that have their signs or symptoms of the Financial Distress. Financial distress is a situation when the company no longer able to fulfill its obligations to the debtor because the company had insufficient funds where total liabilities greater than total assets, and cannot achieve the economic objectives of companies that profit (Almilia \& Herdiningtyas 2005). Is the company registered in BEI 
affect the global economic crisis. Observation period in this study from 2011-2014 a total of 119 mining companies are eligible to be sampled in this study. a. Based on the analysis and hypothesis testing that has been done, it can be concluded as follows:

a. From regression analysis found that adjustedR2 of $100 \%$. This indicates that the variable Financial distress is only able to be explained by the independent variables WCTA, RETA, EBIT and BVOE, without being influenced by other variables.

b. The first hypothesis testing results show that the variable WCTA Net Working Capital to Total Assets positive effect on Financial Distress. Kamal said that if Net Working Capital to Total Assets positive effect on Financial Distress companies are not experiencing symptoms or in bankruptcy.

c. The second hypothesis testing results show that the variable RETA Retained Earnings to Total Asset positive effect on Financial Distress. Kamal said that if Retained Earnings to Total Asset positive effect on Financial Distress, then the company is not in or bankruptcy.

d. The test results indicate that the hypothesis to three variables EBIT Earnings Before Interest and Tax to Total Asset positive effect on Financial Distress, then the company is not in or bankruptcy.

e. The test results showed that hipotesi to four variables BVOE Book Value of Equity to Total Liabilities positive effect on Financial Distress, then the company will experience Financial Distress.

\section{Limitations and Suggestions}

In this study has limitations that can be used as a corrective for future studies, among others:

a. This study is confined to the mining companies, amounting to 119 companies during the period 2011-2014.

b. Companies under investigation should be similar.

c. Only use ratios Altman Z-score modification.

d. Many company's annual report is not complete.

In this study the authors hope these results useful to the reader and can be used as a reference and understanding for everyone, the following benefits from this research:

\section{For Companies}

The results of this study can be used as an evaluation for the company in the global economy mengadapi in attracting investors. As well as a consideration of whether or not to make improvements in some sectors to support the performance of the work and obtain satisfactory results in the future for mining companies in the face of the global economy.

b. For Investor

The results of this study can be used as a reference in analyzing the development of a mining company in Indonesia, which already go international, this disclosure may be used as information to assess the risks in the future, thereby reducing the uncertainty of the results to be obtained in the future for investors.

\section{c. For Academic}

The results of this study can be used as instructional material in the learning process the data and analyze financial distress in companies listed on the Indonesia Stock Exchange. Disclosures made by the management have been helpful for the investors as well as being considered by the authors to conduct research.

In this research still has shortcomings and limitations, the authors give some suggestions for further research to be conducted as input and consideration, namely:

a. In this study only focused on the mining sector consider research object other than the mining sector. b. This study uses a cross section using the criteria in data collection, using time series and panel data can give different results.

c. Only use ratios Altman Z-score, compared with methods other ratios that can support the results obtained

\section{Acknowledgment}

The authors gratefully acknowledge the contributions from Mr. Arif Darmawan for the support and guidance through making this research until it is finished. 


\section{References}

Alifiah, M. N. (2014). Prediction of financial distress companies in the trading and service sector in Malaysia using macroeconomic variable. Social and Behavioral Science 129.

Bal, G. R. (2015). Prediction of Financial Distress using Altman Z-score: A study od Select FMCG Companies. Indian Journal of Applied Research.

Celli, M. (2015). Can Z-score Model Predict Listed

Companies Failures in Italy? an Empirical Test.

International Journal of Business and Management.

Gujarati, D.N., (2003) Basic Econometrics Fourth Edition, Mc. Graw Hill Company, New York.

Kamal, S. M. (2012). Analisis Prediksi kebangkrutan pada perusahaan Perbankan Go public di Bursa Efek Indonesia.

Kumbaro, T. J. (2011). Predicting Corporate Default an Assessment of the Z-score Model on U.S. Market 2007-2010. Degree Project in Corporate and Financial Management.

Odipo, M. \&. (2008). Evaluation of Applicability of Altman's Revised Model in Prediction of Financial Distress : A Case of Companies Quoted in the Nairobi Stock Exchange.

Sindo, K. (2015, September 28). Investasi Sektor Pertambangan dan Energi. Dipetik january 12,

2016, dari Ekonomi Bisnis: www.koran-sindo.com

Sulub, S. A. (2014). Testing the Predictive Power of Altman's Revised Z' Model : The Case 10 Multinational Companies. Research Journal of Finance and Accounting.

Therese Johansson, J. K. (2011). Prediting Corporate Default - an Assessment of the Z-score Model on the U.S Market 2007-2010. Degree Project in Corporate and Financial Management.

Willy, (2011). Model Prediksi Kegagalan Bank Merger

Berdasarkan Rasio Keuangan Model Altman.

Palembang: STIE MUSI. 